\title{
New and Old Immunodeficiencies
}

\author{
E. RICHARD STIEHM
}

UCLA Department of Pediatrics, UCLA School of Medicine, Los Angeles, California 90024

\begin{abstract}
Yesterday's immunodeficiencies emphasized the clinical and familial associations of the syndromes and date from the 1920s (ataxia-telangiectasia, chronic mucocutaneous candidiasis), the 1930s (Wiskott-Aldrich syndrome), skipping the 1940s, but blossoming in the 15-y period from 1950 to 1965 . In this period, primary immunodeficiencies affecting all the major limbs of the immune system were first described (1950: severe combined immunodeficiency; 1952: X-linked agammaglobulinemia; 1957: chronic granulomatous disease; 1965: C2 deficiency). Today's immunodeficiencies, as detailed in Stiehm's Immunologic Disorders in Infants and Children (Edition 1, 1973; Edition 2, 1980; and Edition 3, 1989) emphasize the immunologic and genetic aspects of immunodeficiency. These increased from 43 syndromes in the 1973 edition (34 primary, nine secondary) to 94 syndromes in the 1989 edition (66 primary, 28 secondary). This means that about two primary and one secondary immunodeficiencies have been uncovered annually. Tomorrow's immunodeficiencies, to be covered in Edition 4, will include new clinical and immunologic observations and molecular and biochemical studies that characterize some unique immunodeficiencies. These include the following six groups of defects: 1) neutropenic syndromes with hypogammaglobulinemia, including the WHIM syndrome; 2) phenotypic genetic syndromes with immunodeficiency including Bloom's syndrome and Schimke's immuno-osseous dysplasia; 3) natural killer cell defects associated with $a$ ) other primary immunodeficiencies, $b$ ) other nonimmunologic illness, and c) primary natural killer defects; 4) T-cell membrane defects; 5) IL defects; and 6) miscellaneous phagocytic illnesses including periodontitis and the asplenia syndrome.
\end{abstract} (Pediatr Res 33 (Suppl): S2-S8, 1993)

\section{Abbreviations}

\author{
NK, natural killer
}

TCR, T-cell receptor

\section{YESTERDAY}

Phenotypic syndromes were the first immunodeficiency syndromes described (Table 1), usually without noting the patients' increased susceptibility to infection. These date from the $1920 \mathrm{~s}$ when Syllaba and Henner (2) in Paris described ataxia-telangiectasia and Thorpe and Handley (3) in Philadelphia described mucocutaneous candidiasis. Ataxia-telangiectasia was rediscovered in 1941 by Madame Louis-Bar (4) in Paris and again in 1957 by Boder and Sedgwick (5) in Los Angeles.

In the 1930s, Wiskott (6) in Munich, Germany, identified what is now known as the Wiskott-Aldrich syndrome; this was independently rediscovered in 1954 when Aldrich et al. (7), in Rochester, Minnesota, wrote an article on the subject in English. Glanzmann and Riniker's 1950 paper from Bern, Switzerland, described a fatal case of severe combined immunodeficiency, noting the lymphopenia that accompanied the disorder (8). The 1953 paper of Keidan et al. (9) from Liverpool, UK, described fatal progressive vaccinia in a child with lymphopenia and agammaglobulinemia. The syndrome was further elucidated when siblings of the patient reported in the original paper were again described from Bern in 1958, providing the eponym "Swiss-type agammaglobulinemia" $(10,11)$. Agammaglobulinemia in a 39 y-old woman (common variable immunodeficiency) was first described by Sanford et al. (12) in 1954.

A disorder of the phagocytic system was first identified in 1957 by the Minneapolis group, who described chronic granulomatous disease under the pessimistic name "fatal granulomatous disease of childhood" (13). To complete the discovery of the main types of immunodeficiency, hereditary $\mathrm{C} 2$ deficiency with infection was first described in 1965 by Klemperer et al. (14). References from Ross and Densen's marvelous review (15) of the complement deficiency syndromes provide the information necessary to construct a unique schema, the complement deficiency discovery pathway (Fig. 1), starting in 1965 with C2 deficiency (14) and appropriately terminating with C9 deficiency (16) in 1983.

This brief historical review ends with DiGeorge's description of thymic hypoplasia in 1965 (17), the same year in which this author finished a fellowship and sought gainful employment, thus ending yesterday and starting today.

\section{TODAY}

Today's immunodeficiencies are defined, for this overview, as those covered in my text, Immunologic Diseases in Infants and Children, published in 1973, 1980, 1989, and hopefully 1994 $(18-21)$. The overall incidence of primary immunodeficiency probably has not changed in this two-decade period, remaining at about 1 per 10000 live births (excluding IgA deficiency). However, a larger number of primary immunodeficiencies are recognized and more patients are surviving so that the total number of cases is increasing slowly. As the diverse cells and molecules of the immune system are identified and their interactions explored, more and more distinct disorders have been defined.

The secondary immunodeficiencies, those illnesses resulting from some nonimmunologic primary illness, have, by contrast, 
Table 1. Dates of discovery of some primary immunodeficiencies (1926-1965)

\begin{tabular}{ll}
\hline \multicolumn{1}{c}{ Disorder } & \multicolumn{1}{c}{ Year } \\
\hline Ataxia-telangiectasia $(2,4,5)$ & $1926(1941,1957)^{*}$ \\
Chronic mucocutaneous candidiasis (3) & 1929 \\
Wiskott-Aldrich syndrome (6, 7) & $1937(1955)$ \\
Severe combined immunodeficiency (8-10) & $1950(1953,1958)$ \\
X-linked agammaglobulinemia (1) & 1952 \\
Common variable immunodeficiency (12) & 1954 \\
Chronic granulomatous disease (13) & 1957 \\
C2 deficiency (14, 15) & $1965(1966,1972)$ \\
DiGeorge syndrome (17) & 1965 \\
\hline
\end{tabular}

* Indicates publication dates of other early, seminal papers.

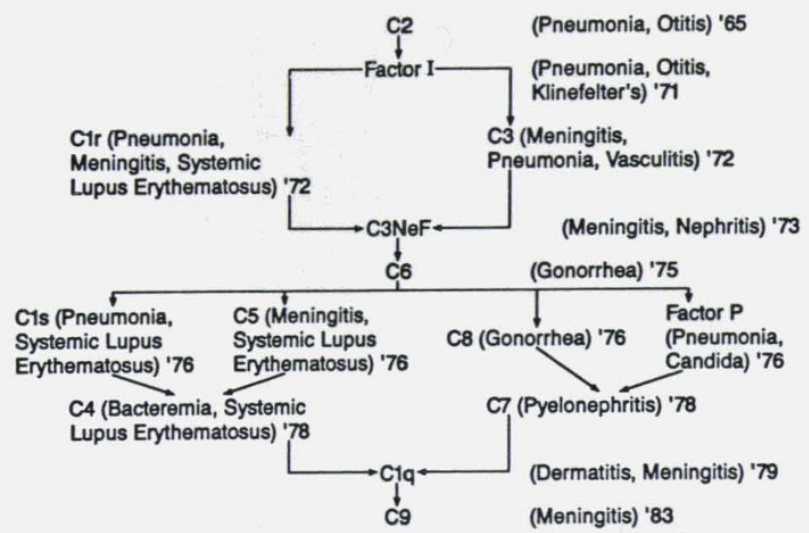

Fig. 1. Complement-infection discovery pathway (Data derivation: Medicine 63:243, 1984).

Table 2. Number of immunodeficiency syndromes described in editions I and III of Immunologic Disorders in Infants and Children

\begin{tabular}{lcc}
\hline & $\begin{array}{c}\text { Edition I } \\
1973(18)\end{array}$ & $\begin{array}{c}\text { Edition III } \\
1989(20)\end{array}$ \\
\hline Secondary immunodeficiencies & 9 & 28 \\
Primary immunodeficiencies & 34 & 66 \\
Antibody deficiencies & 7 & 15 \\
Cellular deficiencies & 10 & 13 \\
Combined deficiencies & 3 & 4 \\
Phagocytic deficiencies & 9 & 16 \\
Complement deficiencies & 5 & 18 \\
Total & 43 & 94 \\
\hline
\end{tabular}

increased dramatically. This can be attributed to such factors as 1 ) increased survival of tiny premature infants and a longer life span, leading to the immunodeficiencies of immaturity and aging; 2) increased use and number of immunosuppressive agents (drugs, radiation, plasmapheresis); 3) better treatment of primary diseases (infections, cancers) with prolonged survival; 4) more transplant procedures; 5 ) better diagnosis of subtle immunodeficiencies; 6) global malnutrition; and 7) the AIDS epidemic.

The growth of immunodeficiency can be readily illustrated by recording the number of primary and secondary immunodeficiency syndromes described in the 1st edition of my text, published in 1973 (18), compared to the 3rd edition, published in 1989 (20). In 1973, nine secondary and 34 primary immunodeficiencies were described, compared to 28 secondary and 66 primary immunodeficiencies in 1989 (Table 2). This means that investigators discovered about two new primary and one new secondary immunodeficiencies annually. As the next edition will indicate, this discovery pattern continues unabated, involving all limbs of the immune system except for complement deficiencies, inasmuch as no new complement components have been added.

Some of the major areas of progress in the field in the last two decades are identified in Table 3. These include multiple new illnesses, new diagnostic techniques, and new and improved treatments, the latter including enzyme (polyethylene glycoladenosine deaminase) therapy, cytokine therapy, i.v. immune globulin, haploidentical bone marrow transplants, and gene therapy. New and better use of antibiotics and antiviral drugs have also contributed to the better outlook for immunodeficient patients.

Almost as interesting as the new advances were the blind alleys. As noted in Table 4, these include diagnoses that are in question (C5 dysfunction) or belong to a better-defined syndrome (the patient with actin dysfunction had leukocyte adhesion deficiency) or have never been confirmed. Certain treatments have been shown to be ineffective (transfer factor) or replaced by better therapies (fetal liver transplantation). Some of these may be resurrected with further refinements (thymic hormone therapy) or under limited circumstances (IgA-deficient plasma for severe $\operatorname{Ig}$ A sensitivity in a patient who needs immune globulin treatment).

\section{TOMORROW}

I have identified six new groups of immunodeficiencies (Table 5) that are as yet unreported in my textbook, but that will be discussed in the next edition. Some of these disorders are new; others have been around for some time, but their description has not been recognized as part of the main stream of immunologic information. AIDS is another of tomorrow's immunodeficiencies, just as it is today's immunodeficiency. The number of

Table 3. Advances in immunodeficiency 1973-1989

New illnesses
AIDS
Leukocyte adhesion deficiency
Bare lymphocyte syndrome
IgG subclass deficiencies
Complement deficiencies
Adenosine deaminase deficiency
Hypogammaglobulinemia with growth hormone deficiency
Polysaccharide unresponsiveness
Cocarboxylase deficiency with candidiasis
Specific granule deficiency
New diagnostic procedures
MAb markers and flow cytometry
Complement component analysis
Ig subclass measurements
New treatments
Antibiotics and antivirals, prophylaxis, and treatment
Intravenous immune globulin
Haploidentical bone marrow transplantation
Enzyme therapy: polyethylene glycol-adenosine deaminase
Cytokine therapy: IL-2, interferon- $\gamma$, granulocyte-colony stimulating
factor
Gene therapy: adenosine deaminase deficiency

Table 4. Abandoned concepts in immunodeficiency 1973-1989

Discarded illnesses

Immunologic attrition disease

Immunologic amnesia

C5 dysfunction

Lazy leukocyte syndrome

Actin dysfunction

Discarded treatments

Plasma therapy

Fetal thymus/epithelial transplantation

Fetal liver transplantation

Thymic hormone

Transfer factor

Levamisole/isoprinosine 
Table 5. Tomorrow's immunodeficiencies

Neutropenic syndromes with hypogammaglobulinemia

Phenotypic genetic syndromes with immunodeficiency

NK cell defects

Signaling and T-cell receptor/T-cell immunodeficiencies

Immunodeficiencies due to IL abnormalities

Phagocytic defects: periodontitis, asplenia

Table 6. Familial syndromes with hypogammaglobulinemia and neutropenia*

X-linked agammaglobulinemia

Common variable immunodeficiency

Immunodeficiency with hyper-IgM

Cyclic neutropenia

Schwachman syndrome

Ataxia-telangiectasia

Reticular dysgenesis

Short-limbed dwarfism

Partial albinism and immunodeficiency

WHIM syndrome $\dagger$

* From Wetzler et al. (1989). ${ }^{22}$

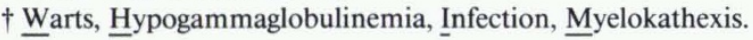

\section{Table 7. Phenotypic genetic syndromes with immune} abnormalities

Down's syndrome

Ataxia-telangiectasia

Short-limbed dwarfism/cartilage hair hypoplasia

Adenosine deaminase deficiency

Schwachman syndrome

Bloom's syndrome

Schimke's immuno-osseous dysplasia

papers on AIDS is increasing as rapidly as the spread of the epidemic; these efforts will continue to expand the knowledge of the cause and consequences of T-cell immunodeficiency.

The first group to be considered are the familial neutropenic syndromes with hypogammaglobulinemia as summarized in Table 6. This table is derived from a recent article by Wetzler $e t$ al. (22) and includes their description of a new familial neutropenic syndrome: the WHIM syndrome. This is an illness described in two sisters (aged 22 and 23) who had Warts, $\underline{\text { Hypogam- }}$ maglobulinemia, Infections, and Myelokathexis, the latter referring to retention of leukocytes within a hypercellular marrow. Ig and B cells were low but not absent in the patients, and mitogeninduced proliferative responses and delayed hypersensitivity tests were somewhat decreased. The bone marrow was hypercellular with a shift to the right and many mature myeloid cells.

This and other hereditary immunodeficiencies with neutropenia emphasize the close relationship between the immune system and the control of myelopoiesis. High-dose i.v. immune globulin therapy often reverses the neutropenia in patients with $\mathrm{X}$-linked agammaglobulinemia and the hyper-IgM syndrome. A unifying hypothesis is sorely needed.

A second group of intriguing immunodeficiencies are the phenotypic genetic syndromes with immune abnormalities. Table 7 details several familiar and not so familiar syndromes that almost always have one or more immune defects. Bloom's syndrome and Schimke's immuno-osseous dysplasia are new arrivals on this list and deserve some comment.

Bloom's syndrome (23-27) is an autosomal recessive syndrome of growth retardation, peculiar physiognomy, hypogonadism, and telangiectatic erythema of the face associated with sun sensitivity. There is a high frequency of chromosome breakage and increased risk for the development of lymphoid malignancy. Several papers have detailed the immunologic abnormalities associated with Bloom's syndrome, accounting for increased susceptibility to infection beginning early in life. These include

Table 8. Other genetic syndromes reported with immune abnormalities

Progeria $^{31}$ (Hutchinson-Gilford syndrome)

Congenital folic acid malabsorption ${ }^{32}$

Familial microcephaly with normal $\mathrm{IQ}^{33}$

Ectodermal dysplasia with aplastic anemia ${ }^{34}$

Rubinstein-Tabyi syndrome $\mathrm{e}^{35}$

Schwartz-Jampel syndrome ${ }^{36}$

Xeroderma pigmentosa ${ }^{37,38}$

Chromosome 18 abnormalities ${ }^{39,40}$

Table 9. Immunodeficiency with NK cell defects

Primary immunodeficiencies with NK cell deficiency

Severe combined immunodeficiency ${ }^{41}$

Reticular dysgenesis ${ }^{42}$

Common variable immunodeficiency with monocyte dysfunction ${ }^{43}$

Chediak-Higashi syndrome $e^{44-47}$

Leukocyte adhesion deficiency ${ }^{48}$

Other syndromes with NK cell deficiency

Hodgkin's disease ${ }^{49}$

Xeroderma pigmentosum ${ }^{38}$

Lymphohistiocytosis $^{50}$

Pre-leukemia and leukemia ${ }^{51,52}$

Pure red-cell aplasia ${ }^{53}$

Depression/bereavement ${ }^{54}$

Bloom's syndrome ${ }^{26}$

AIDS $^{55}$

Chronic fatigue syndrome ${ }^{56}$

Primary immunodeficiency due to selective NK cell deficiency

Lipinski et al., $1980^{57}$

Four unrelated children with infections, aged 2 to 13 , all had decreased interferon- $\gamma$ production; two had partial albinism

Biron et al., $1989^{58}$

13-y-old girl with severe herpes virus infections

Komiyama et al., $1990^{59}$

12-y-old male with Hodgkin's; 6-y-old brother has respiratory infection and adenopathy

Table 10. Membrane T-cell defects with immunodeficiency

\begin{tabular}{|c|c|c|}
\hline Author & Patient description & Defect \\
\hline Alarcon et al., $1988^{60}$ & $\begin{array}{l}\text { 3-y-old boy with SCID* } \\
6 \text {-y-old brother is nor- } \\
\text { mal }\end{array}$ & $\begin{array}{l}\text { Abnormal T-cell } \\
\text { receptor }\end{array}$ \\
\hline Geisler et al., $1989^{61}$ & $\begin{array}{l}\text { 6-y-old girl with pneu- } \\
\text { monia } \\
\text { 5-y-old brother died } \\
\text { with thymic dysplasia }\end{array}$ & $\begin{array}{l}\text { Abnormal T-cell } \\
\text { receptor }\end{array}$ \\
\hline Chatila et al., $1989^{62}$ & $\begin{array}{l}\text { 9-y-old boy with infec- } \\
\text { tions and autoim- } \\
\text { mune hemolytic ane- } \\
\text { mia }\end{array}$ & $\begin{array}{l}\text { Defective signal } \\
\text { transduction }\end{array}$ \\
\hline Rijkers et al., $1991^{63}$ & $\begin{array}{l}\text { 8-y-old boy with fatal } \\
\text { pneumonia }\end{array}$ & $\begin{array}{l}\text { Defective signal } \\
\text { transduction }\end{array}$ \\
\hline
\end{tabular}

* SCID, severe combined immunodeficiency.

impaired proliferative responses to mitogens, decreased pokeweed mitogen-stimulated $\mathrm{Ig}$ synthesis in vitro, decreased responses in the mixed leukocyte reaction, diminished NK activity with normal NK cell number, slightly decreased serum Ig, and reduced CD4 $\mathrm{T}$ cells (23-27).

Schimke's immuno-osseous dysplasia is an autosomal recessive skeletal dysplasia with dwarfism, progressive nephropathy, pigmentary skin changes, lymphopenia, and recurrent infections $(28,29)$. There is increased urinary excretion of chondroitin-6sulfate in some patients. Immunologic abnormalities include decreased CD4 cells, decreased proliferative responses, decreased $\mathrm{CD} 3$ cells with an $\alpha / \beta$ TCR, and thymic atrophy with abnormal 
Table I I. IL-2 immunodeficiency syndromes

\begin{tabular}{|c|c|}
\hline Chu et al., $1984^{64}$ & $\begin{array}{l}\text { 10-y-old Lebanese boy with recurrent } \\
\text { infections and partial T-cell defi- } \\
\text { ciency }\end{array}$ \\
\hline Doi et al., $1988^{65}$ & $\begin{array}{l}\text { 21-y-old Japanese man with recur- } \\
\text { rent infections and partial T-cell } \\
\text { deficiency. Parents were first cou- } \\
\text { sins. Brother died at age } 17 \text { with } \\
\text { combined immunodeficiency }\end{array}$ \\
\hline $\begin{array}{l}\text { Pahwa et al., } 1989^{66} \\
\text { Geha et al., } 1991^{67}\end{array}$ & $\begin{array}{l}\text { 4-y-old girl with SCID* despite nor- } \\
\text { mal B- and T-cell numbers. Two } \\
\text { BMT } \dagger \text { were unsuccessful. IL-2 } \\
\text { treatment was very successful }\end{array}$ \\
\hline $\begin{array}{l}\text { Weinberg and Parkman, } \\
1990^{68}\end{array}$ & $\begin{array}{l}\text { 12-mo-old Salvadorian infant died } \\
\text { with SCID at } 1 \text { y despite two BMT }\end{array}$ \\
\hline
\end{tabular}

* SCID, severe combined immunodeficiency.

† BMT, bone marrow transplant.

Hassall's corpuscles and abnormal histology. This illness emphasizes the common association of skeletal and immune system abnormalities (30). Several other genetic syndromes are reported with inconsistent immune abnormalities (Table 8). Most have T-cell defects, although chromosome 18 abnormalities have IgA deficiency. As these defects are localized to specific chromosomes or chromosome regions, multiple regulatory interactions within the T-cell system will become better defined.

A third new group of immunodeficiencies are the NK cell defects outlined in Table 9. These can be divided into three groups: 1) well-recognized immunodeficiencies whose immunologic defect includes NK deficiency, 2) miscellaneous syndromes in which NK deficiency has been identified, and 3) primary immunodeficiencies due to absent or decreased NK function.

Primary immunodeficiencies may have an NK defect as part of a generalized defect in lymphocyte development, such as in severe combined immunodeficiency or reticular dysgenesis (41, 42). Lack of a specific surface glycoprotein on all leukocytes prevents target cell binding and decreased cytotoxicity in the leukocyte adhesion deficiency syndrome (48). The best described and most consistent NK deficiency occurs in the ChediakHigashi syndrome (44-47); this is associated with a normal number of NK cells but delayed postbinding lysis (47).

Several other illnesses have been noted to have depressed NK activity (Table 9). The relationship of the NK deficit to the pathogenesis of these disorders is often obscure; in AIDS, however, it may be associated with progression of illness.

Seven patients with frequent severe infections who have an isolated NK defect have been described (Table 9). The patient described by Biron et al. (58) with recurrent otitis and severe herpes infection (life threatening varicella) is particularly interesting; she had neither NK cells, NK precursors, nor NK function, but except for recurrent neutropenia all other immune tests were normal.

A fourth group of illnesses are T-cell membrane defects (Table 10). These all have defective T-cell activation with poor prolif- erative responses to mitogens and antigens, variable $\mathrm{T}$-cell functional deficiency, and mild to severe susceptibility to infection (60-63). Two of these patients have a structurally abnormal TCR; one lacked the CD3- $\zeta$ chain (60), and the second had deficient $\alpha / \beta$ TCR-CD3 cells and a great excess of $\gamma / \delta$ TCRCD3 cells (61).

The lymphocyte defect of one of the two patients with abnormal signal transduction could be corrected by calcium ionophore and phorbol, suggesting a defect in signal generation coupled to the G-protein second messenger system (62). In the second patient (63), the exact defect of signal transduction could not be identified, but there were abnormally high intracellular $\mathrm{Ca}^{++}$and phosphatidylcholine/phosphatidylserine ratio after phytohemagglutinin proliferation. In all these cases, failure of T-lymphocyte activation occurs, leading to immunodeficiency. Because of the complexity of the activation pathway, many more defects will undoubtedly be identified.

The fifth new area of immunodeficiency is deficient production of specific cytokines, now numbering well over 15 examples. These defects are particularly important to identify because they may sometimes be treated by administration of a recombinant form of the missing cytokine.

The best described IL defect involves deficiency of IL-2 (6468). The clinical histories of four such infants are shown in Table 11. All had partial or severe T-cell deficiency. One child improved dramatically with IL-2 therapy (66). Defective mRNA production for IL-2, IL-3, IL-4, and IL-5 was noted in one patient. It is of interest that IL-2 deficiency is compatible with prolonged survival and partially intact immune function.

Undoubtedly, other IL defects will be found. Multiple IL may be reduced in X-linked agammaglobulinemia and common variable immunodeficiency, but whether they represent the fundamental defect is not known. In addition, several patients (56) have deficient interferon- $\gamma$ synthesis as well as decreased NK function. Excessive IL-6 synthesis may be present in hyper-IgE syndrome and Castleman's disease (69).

Phagocytic defects constitute the final group of new immunodeficiencies. Leukocyte adhesion deficiency has been described previously; much new information about this disorder is now available. One phagocytic deficiency syndrome that is not well described is early onset periodontal disease syndrome as summarized in Table 12. There are two forms of this disease; both have early onset of periodontitis with tooth and alveolar bone loss. This may be associated with an abnormality of a neutrophil surface protein (gp110) and a severe chemotactic defect (70).

The latest syndrome to be described is asplenia, the congenital absence of the spleen. Wang and Hsieh (71) have identified a subtle T-cell defect, in addition to the expected decrease in phagocytosis of opsonized cells and bacteria. The role of tuftsin in this disorder needs clarification. There may be an associated antibody defect to polysaccharide antigens (72).

Tomorrow's defects, being only a day away, can be anticipated with some certainty. What illnesses will emerge the day after tomorrow are much more problematic. Recognizing and treating them are tasks for the next generation of pediatric investigators.

Table 12. Early onset periodontal disease*

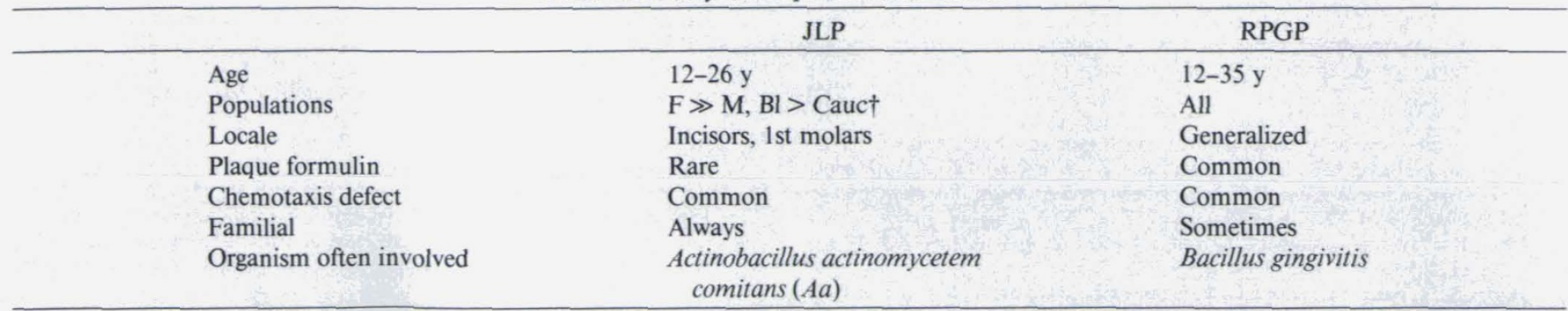

* Juvenile localized periodontitis (JLP) vs rapidly progressive generalized periodontitis (RPGP). Data from reference 70 .

$\dagger$ F, female; M, male; Bl, black; Cauc, Caucasian. 


\section{REFERENCES}

1. Bruton OC 1952 Agammaglobulinemia. Pediatrics 9:722-728

2. Syllaba L, Henner K 1926 Contribution a l'indépendance de l'athetose double idiopathique et congenitale: atteinte familiale, syndrome dystrophique, signe du réseau vasculaire conjonctival, intégrité psychique. Rev Neurol (Paris) 1:541-562

3. Thorpe ES, Handley HE 1929 Chronic tetany and chronic mycelial stomatitis in a child aged four and one-half years. Am J Dis Child 38:328-338

4. Louis-Bar D 1941 Sur un syndrome progressif comprenant des telangiectasies capillaires cutanées et conjonctivales symétriques $\alpha$ disposition naevoîde et des troubles cérébelleux. Confin Neurol 4:32-42

5. Boder E, Sedgwick RP 1957 Ataxia-telangiectasia: a familial syndrome of progressive cerebellar ataxia, oculocutaneous telangiectasia and frequent pulmonary infection. Univ South Calif Med Bull 9:15-27

6. Wiskott A 1937 Familiarer, angeborener Morbus Werihofii? Aschr Kinderheilk 68:212-216

7. Aldrich RA, Steinberg AG, Campbell DC 1954 Pedigree demonstrating a sexlinked recessive condition characterized by draining ears, exzematoid dermatitis and bloody diarrhea. Pediatrics 13:133-139

8. Glanzmann E, Riniker P 1950 Essentielle lymphocytophthise. Ein neues Krankheitsbildaus der Sauglings-pathologie. Ann Paediatr (Basel) 175:1-32

9. Keidan SE, McCarthy K, Haworth JC 1953 Fatal generalized vaccinia with failure of antibody production and absence of serum gamma globulin. Arch Dis Child 28:110-116

10. Tobler R, Cottier H 1958 Familiare lymphopenie mit agammaglobulinamie und schwere moniliasis: die "essentielle lymphocytophthise": als besondere form der fruhkindliehen agammaglobulinamie. Helv Paediatr Acta 13:313338

11. Hitzig WH, Biro Z, Bosch H, Huser HJ 1958 Agammaglobulinamie und Alymphozytose mit Schwund des lymphatischen Gewebes. Helv Paediatr Acta 13:551-585

12. Sanford JP, Favour CB, Tribeman MS 1954 Absence of serum gamma globulins in an adult. N Engl J Med 250:1027-1029

13. Berendes H, Bridges RA, Good RA 1957 A fatal granulomatous disease of childhood: the clinical study of a new syndrome. Minn Med 40:309-312

14. Klemperer MR, Woodworth HC, Rosen FS, Austen KF 1965 Hereditary deficiency of the second component of human complement: transmission as an autosomal codominant tract. J Lab Clin Med 66:886(abstr)

15. Ross SC, Densen P 1984 Complement deficiency states and infection: epidemiology pathogenesis and consequences of Neisserial and other infections in an immune deficiency. Medicine 63:243-273

16. Fine DP, Gewurz H, Griffiss M, Lint TF 1983 Meningococcal meningitis in a woman with inherited deficiency of the ninth component of complement. Clin Immunol Immunopathol 28:413-417

17. DiGeorge AM 1965 A new concept of the cellular basis of immunity (discussion). J Pediatr 67:907-908

18. Stiehm ER, Fulginiti VA 1973 Immunologic Disorders in Infants and Children. WB Saunders Co, Philadelphia

19. Stiehm ER, Fulginiti VA 1980 Immunologic Disorders in Infants and Children, Ed II. WB Saunders Co, Philadelphia

20. Stiehm ER 1989 Immunologic Disorders in Infants and Children, Ed III. WB Saunders Co, Philadelphia

21. Stiehm ER 1994 Immunologic Disorders in Infants and Children, Ed IV. WB Saunders Co, Philadelphia (in press)

22. Wetzler M, Talpaz M, Kleinerman ES, King A, Huh YO, Gutterman JU, Kurzrock R 1990 A new familial immunodeficiency disorder characterized by severe neutropenia, a defective marrow release mechanism, and hypogammaglobulinemia. Am J Med 89:663-672

23. Hutteroth TH, Litwin SD, German J 1975 Abnormal immune responses of Bloom's syndrome lymphocytes in vitro. J Clin Invest 56:1-7

24. Weemaes CMR, Bakkeren JA, ter Haar BG, Hustinx TW, van Munster PJ 1979 Immune responses in four patients with Bloom's syndrome. Clin Immunol Immunopathol 12:12-19

25. Taniguchi N, Mukai M, Nagaoki T, Miyawaki T, Moriya N, Takahashi H, Kondo N 1982 Impaired B-cell differentiation and T-cell regulatory function in four patients with Bloom's syndrome. Clin Immunol Immunopathol 22:247-258

26. Ueno Y, Miyawaki T, Seki H, Hara K, Sato T, Taniguchi N, Takahashi H, Kondo N 1985 Impaired natural killer cell activity in Bloom's syndrome could be restored by human recombinant IL-2 in vitro. Clin Immunol Immunopathol 35:226-233

27. Van Kerckhove CW, Ceuppens JL, Vanderschueren-Lodeweyckx M, Eggermont E, Vertessen S, Stevens EA 1988 Bloom's syndrome: clinical features and immunologic abnormalities of four patients. Am J Dis Child 142:10891093

28. Schimke RN, Horton WA, King CR 1971 Chrondroitin-6-sulphaturia, defective cellular immunity, and nephrotic syndrome. Lancet 2:1088-1089

29. Spranger J, Hinkel GK, Stoss H, Thoenes W, Wargowski D, Zepp F 1991 Schimke immuno-osseous dysplasia: a newly recognized multisystem disease. J Pediatr 119:64-72

30. Hong R 1989 Associations of the skeletal and immune systems. Am J Med Genet 34:55-59

31. Harjacek M, Batinic D, Sarnavka V, Uzarevic B, Mardesic D, Marusic M 1990 Immunological aspects of progeria (Hutchinson-Gilford syndrome) in a 15month-old child. Eur J Pediatr 150:40-42

32. Gross RL, Reid JVO, Newberne PM, Burgess B, Marston R, Hift W 1975
Depressed cell-mediated immunity in megaloblastic anemia due to folic acid deficiency. Am J Clin Nutr 28:225-232

33. Seemanová E, Passarge E, Beneskova D, Houstěk J, Kasal P, Sevčiková M 1985 Familial microcephaly with normal intelligence immunodeficiency, and risk for lymphoreticular malignancies: a new autosomal recessive disorder. Am J Med Genet 20:639-648

34. Malamed J, Rubinstein A, Kadish A, Manabe T, Santorineou M, Einhorn A 1978 Impairment of cell-mediated immunity in ectodermal dysplasia with aplastic anemia. Helv Paediatr Acta 33:169-176

35. Rivas F, Fragoso R, Ramos-Zepeda R, Vaca G, Hernandez A, GonzalezQuiroga G, Olivares N, Cantu JM 1980 Deficient cell immunity and mild intermittent hyperaminoacidemia in a patient with the Rubinstein-Taybi syndrome. Acta Paediatr Scand 69:123-125

36. Mollica F, Messina A, Stivala F, Pavone L 1979 Immuno-deficiency in Schwartz-Jampel syndrome. Acta Paediatr Scand 68:133-135

37. Dupuy JM, Lafforet D 1974 A defect of cellular immunity in xeroderma pigmentosum. Clin Immunol Immunopathol 3:52-58

38. Norris PG, Limb GA, Hamblin AS, Hawk JL 1988 Impairment of naturalkiller-cell activity in xeroderma pigmentosum. N Engl J Med 319:16681669

39. Feingold M, Schwartz RS, Atkins L, Anderson R, Bartsocas CS, Page DL, Littlefield JW 1969 IgA deficiency associated with partial deletion of chromosome 18. Am J Dis Child 117:129-136

40. Stewart J, Go S, Ellis E, Robinson A 1970 Absent IgA and deletions of chromosome 18. J Med Genet 7:11-19

41. Koren HS, Amos DB, Buckley RH 1978 Natural killing in immunodeficient patients. J Immunol 120:796-799

42. Chin TW, Plaeger-Marshall S, Haas A, Ank BJ, Stiehm ER 1989 Lymphokineactivated killer cells in primary immunodeficiencies and acquired immunodeficiency syndrome. Clin Immunol Immunopathol 53:449-459

43. Clerici M, Villa ML, Mantovani M, Rugarli C 1988 NK cell activity and monocyte dysfunctions in a patient with common variable hypogammaglobulinemia. J Clin Lab Immunol 27:143-147

44. Roder JC, Haliotis T, Klein M, Korec S, Jett JR, Ortaldo J, Heberman RB, Katz P, Fauci AS 1980 A new immunodeficiency disorder in humans involving NK cells. Nature 284:553-556

45. Abo T, Roder JC, Abo W, Cooper MD, Balch CM 1982 Natural killer (HNK$1+)$ cells in Chediak-Higashi patients are present in normal numbers but are abnormal in function and morphology. J Clin Invest 70:193-197

46. Katz P, Zaytoun AM, Fauci AS 1982 Deficiency of active natural killer cells in the Chediak-Higashi syndrome. J Clin Invest 69:1231-1238

47. Targan SR, Oseas R 1983 The "lazy" NK cells of Chediak-Higashi syndrome. J Immunol 130:2671-2674

48. Kohl S, Springer TA, Schmalstieg FC, Loo LS, Anderson DC 1984 Defective natural killer cytotoxicity and polymorphonuclear leukocyte antibody-dependent cellular cytotoxicity in patients with LFA-1/OKM-1 deficiency. J Immunol 133:2972-2978

49. Komiyama A, Kawai H, Yamada S, Kato M, Yanagisawa M, Miyagawa Y, Akabane T 1987 A killing defect of natural killer cells with the absence of natural killer cytotoxic factors in a child with Hodgkin's disease. Blood 69:1686-1690

50. Perez N, Virelizier JL, Arenzana-Seisdedos F, Fischer A, Griscelli C 1984 Impaired natural killer activity in lymphohistiocytosis syndrome. J Pediatr 104:569-573

51. Takaku S, Takaku F 1981 Natural killer cell activity and preleukaemia. [letter] Lancet 2:1178

52. Gabrilovac J, Rajic L, Martin-Kleiner I, Osmak M, Batinic D, Tiefenbach A, Boranic M 1989 Defect of NK activity in children with untreated acute lymphocytic leukemia (ALL). I. Dependence on the blast count and phenotype, and response to exogenous and endogenous $\alpha$-interferon. J Clin Lab Immunol 29:9-15

53. Abrahamov A, Schlesinger M 1990 Absence of natural killer cells in a child with pure red blood cell aplasia Am J Hematol 35:258-262

54. Irwin M, Daniels M, Smith T, Bloom E, Weiner H 1987 Impaired natural killer cell activity during bereavement. Brain Behav Immunol 1:98-104

55. Rook AH, Masur H, Lane HC, Frederick W, Kasahara T, Macher AM, Djeu JY, Manischewitz JF, Jackson L, Fauci AS, Quinnan GV 1983 Interleukin2 enhances the depressed natural killer and cytomegalovirus-specific cytotoxic activities of lymphocytes from patients with the acquired immune deficiency syndrome. J Clin Invest 72:398-403

56. Caligiuri M, Murray C, Buchwald D, Levine H, Cheney P, Peterson D, Komaroft AL, Ritz J 1987 Phenotypic and functional deficiency of natural killer cells in patients with chronic fatigue syndrome. J Immunol 139:33063313

57. Lipinski M, Virelizier JL, Tursz T, Griscelli C 1980 Natural killer and killer cell activities in patients with primary immunodeficiencies or defects in immune interferon production. Eur J Immunol 10:246-249

58. Biron CA, Byron KS, Sullivan JL 1989 Severe herpes virus infections in an adolescent without natural killer cells. N Engl J Med 320:1731-1736

59. Komiyama A, Kawai H, Yabuhara A, Yanagisawa M, Miyagawa Y, Ota M, Hasekura H, Akabane T 1990 Natural killer cell immunodeficiency in siblings: defective killing in the absence of natural killer cytotoxic factor activity in natural killer and lymphokine-activated killer cytotoxicities. Pediatrics 85:323-330

60. Alarcon B, Regueiro JR, Arnaiz-Villena A, Terhorst C 1988 Familial defect in the surface expression of the T-cell receptor-CD3 complex. N Engl J Med 319:1203-1208 
61. Geisler C, Pallesen G, Platz P, Odum N, Dickmeiss E, Ryder LP, Svejgaard A, Plesner T, Larsen JK, Koch C 1989 Novel primary thymic defect with T lymphocytes expressing $\mathrm{T}$ cell receptor. J Clin Pathol 42:705-711

62. Chatila T, Wong R, Young M, Miller R, Terhorst C, Geha RS 1989 An immunodeficiency characterized by defective signal transduction in $\mathrm{T}$ lymphocytes. N Engl J Med 320:696-702

63. Rijkers GT, Scharenberg JGM, Van Dongen JJM, Neijens HJ, Zegers BJ 1991 Abnormal signal transduction in a patient with severe combined immunodeficiency disease. Pediatr Res 29:306-309

64. Chu ET, Rosenwasser LJ, Dinarello CA, Rosen FS, Geha RS 1984 Immunodeficiency with defective T-cell response to interleukin 1. Proc Natl Acad Sci USA 81:4945-4949

65. Doi S, Saiki O, Tanaka T, Ha-Kawa K, Igarashi T, Fujita T, Taniguchi T, Kishimoto S 1988 Cellular and genetic analyses of IL-2 production and IL2 receptor expression in a patient with familial T-cell-dominant immunodeficiency. Clin Immunol Immunopathol 46:24-36

66. Pahwa R, Chatila T, Pahwa S, Paradise C, Day NK, Geha R, Schwartz SA Slade H, Oyaizu N, Good RA 1989 Recombinant interleukin 2 therapy in severe combined immunodeficiency. Proc Natl Acad Sci USA 86:5069-5073

67. Geha RS, Castigli E, Chatila T 1991 Novel immune deficiencies: defective transcription of lymphokine genes. Clim Immunol Immunopathol 61:S16S20

68. Weinberg K, Parkman R 1990 Severe combined immunodeficiency due to a specific defect in the production of interleukin-2. N Engl J Med 322:17181723

69. Yoshizaki K, Matsuda T, Nishimoto N, Kuritani T, Taeho L, Aozasa K, Nakahata T, Kawai H, Tagoh H, Komori T 1989 Pathogenic significance of interleukin-6 (IL-6/BSF-2) in Castleman's disease. Blood 74:1360-1367

70. Boughman JA, Astemborski JA, Blitzer MG 1990 Early onset periodontal disease: a genetics perspective. Oral Biol Med 1:89-99

71. Wang J-K, Hsieh K-H 1991 Immunologic study of the asplenia syndrome. Pediatr Infect Dis J 10:819-822

72. Gaines AD, Buckley RH 1989 Impaired antibody response to polysaccharides in association with functional asplenia. J Pediatr 114:89-91

\section{FLOOR DISCUSSION}

Dr. Ballow: Tuftsin deficiency-is that a real entity? I am asked that question frequently and I do not know how to deal with it.

Dr. Stiehm: I am going to turn that question over to Dr. Laurence Boxer.

Dr. Boxer: Tuftsin deficiency was originally described by Nadger from Tufts in the 1970s. Employing Tom Stossel's quantitative assay for phagocytosis, one cannot demonstrate any enhancement of phagocytosis. I think tuftsin deficiency is truly an artifact.

I would like to comment on the phagocytic disorders, some of them which you dismissed and some which you said are new. First of all, I believe the actin dysfunction, which Tom Stossel and I described in 1974 before monoclonal antibodies were available, is a distinct abnormality. In a paper published in Blood last year, Tom Coates and Tom Howard described another patient who apparently lacks the $47-\mathrm{kD}$ cytoplasmic protein that is involved in actin regulation. We studied our particular patient with Harvey Colten and looked at complement receptors on the surface of the child's neutrophils. This child had many of the similar phenotypes of the lab patients, but did have receptors for complement, and his monocytes appeared to phagocytose particles. There was a clear-cut abnormality in the ability of the child's neutrophil actin to polymerize, which is not the case with the lab patients. Therefore, I would not dismiss the actin dysfunction syndrome.

The lazy leukocyte syndrome, described by Spike Miller in Lancet, was the first observation of a chemotactic defect. It was a descriptive disorder of myeloid hyperplasia in the bone marrow and the failure of release of neutrophils into the circulation; Miller then showed a chemotactic defect. Recently, David Dale and I had an opportunity to review 125 bone marrows of patients that had been randomized as part of the G-CSF (granulocyte colony-stimulating factor) trial for the treatment of neutropenic patients. We found three patients who, at least clinically, fit the lazy leukocyte syndrome. They had marrow hyperplasia with maturation right up through the neutrophil form and failure of release of neutrophils into the circulation. Myelokathexis, the WHIM syndrome, was originally described by Wolf Zuelzer in the New England Journal of Medicine in the 1970s. It is a distinct abnormality in morphology of the neutrophils. The lobes of the segmented neutrophils are connected by thin filaments and one sees binucleated myelocytes and promyelocytes. In our study with the neutropenic patients, we have identified three patients with the WHIM syndrome. I do not think the two patients in Texas have a distinct syndrome different from the one Zuelzer described.

Dr. Schwartz: Dr. Stiehm, as you know, levamisole has now been approved for use as adjuvant therapy in colon carcinoma. Now that it is available without going through various INDs etc., we have had the chance to look at a couple of patients with Larry Boxer. Quite some time ago, Savita Pahwa and I saw some patients with T-cell deficiencies who seemed to respond reasonably well to levamisole. And of course the clinical trials that were used to substantiate its use for adjuvant therapy of colon carcinoma suggested that levamisole does have immunopotentiating activity. You might want to keep a reference to it in the fourth edition of your book.

Dr. Gupta: We are evaluating a patient with what might be a new syndrome. I would like to know if anyone in the audience has a similar case. In addition to what one finds in the WHIM syndrome, our patient, a young lady, presented with more generalized symptoms with some increase in upper respiratory tract infection, hypogammaglobulinemia, neutropenia, and thrombocytopenia. We are looking at the defects in more detail in this patient. There is no evidence of any malignancy, lymphoma, or an immunoglobulin gene variant, so we may be looking at another immunodeficiency.

Dr. Filipolvich: You mentioned transplant recipients-do you have any composite information on infants of former transplant recipients who were receiving continuous immunosuppression during the pregnancy?

Dr. Stiehm: No, I have not. That is an interesting question though.

Dr. Filipolvich: We have one patient whom we have followed now for $4 \mathrm{y}$ who was born to a mother who had received a renal graft and was on cyclosporine and immuran during the entire pregnancy. The baby was born at 34 wk with no white cells whatsoever, was T-cell deficient during the first year of life, but now at $4 \mathrm{y}$ is indistinguishable from normal.

Dr. Stiehm: That is very interesting.

Dr. Ochs: Dr. Stiehm, since you mentioned some of the controversial syndromes of yesterday, I think we should also talk about some of the controversial syndromes of the future. Would you comment on the so-called chronic fatigue syndrome, which, in the literature at least, is being more and more associated with some not-so-well-defined T-cell abnormalities.

Dr. Stiehm: Yes, chronic fatigue syndrome is really mysterious. Dr. Jay Levy, who is in the audience, has studied this syndrome, but, as someone said, it is really hard to find an organic disease that occurs only in college-educated, upper middle class, white women, but that is the epidemiology of chronic fatigue syndrome. I have seen about 30 or 40 patients who were referred to me and have looked for immunologic abnormalities. Thus far I have not seen any. However, I think that there are investigators who do see immunologic abnormalities in these patients. Maybe Dr. Levy would like to comment.

Dr. Levy: I have not seen the immunologic defects that have been described in chronic fatigue syndrome, but I think we have to stay away from that subject. It is very controversial. In my experience, the patients with chronic fatigue syndrome are not all college-age. Let me say that in Japan there are a large number of cases of what they are calling NK-cell-deficiency syndrome. The chronic fatigue syndrome can also be seen in depression and bereavement.

I have another question. Maybe the information is not available, but would you speculate as to how many of these syndromes have led to the discovery of new growth factors, new membrane proteins, or new functions of cells? In other words, if one started from the syndrome, has it led to something that was not known, 
rather than taking something that was known and then asking if there was a defect?

Dr. Stiehm: You make a very good point. Initially, of course, clinical observations triggered the immunologic findings, as with agammaglobulinemia. Nowadays, most of the obvious syndromes have been discovered, and we are now reversing ourselves in finding the defects first and then finding a patient that has those defects.

Dr. Strober: Just a comment about primary NK-cell deficiency. Patients with X-linked immunodeficiency syndrome, for instance, very frequently have reduced NK function, and when you look at these patients, they have very poor lymphokine production. It is probable that this is a secondary phenomenon. I feel that the burden of proof is on us to show that there is really a primary NK-cell deficiency, rather than one that is secondary to some much more broadly based abnormality.

Dr. Levy: In my experience, it seems that the chronic fatigue syndrome is a real entity, but I think it is going to turn out to be a mixed bag. The current Annals of Internal Medicine includes an analysis of the Lake Tahoe epidemic of chronic fatigue syndrome, which was originally billed as an EBV (Epstein-Barr virus) infection but later turned out not to be. Robert Gallo, whose name is on the paper, claims to have grown out herpes virus 6 (HHV-6) from a very large percentage of the cells of those patients; whether that is causative or secondary is unclear.

Dr. Frank: What was reported was an abnormality of cells that looked like they were infected by HHV-6, but were actually large macrophages. Before we get carried away with HHV-6, we should beware of observations which are reported on a morphologic basis rather than on real serologic information.

Dr. Levy: The authors did not make the claim that it was causative. In my former position, in the Laboratory of Clinical Investigation, Steve Strauss admitted a fair number of patients with chronic fatigue syndrome, and it was clear that those patients had something. What they have is very unclear, but I think it would be premature to dismiss chronic fatigue syndrome as simply a psychiatric disorder. 